\title{
NATIONAL EDUCATION PHILOSOPHY: A REVIEW OF ITS APPLICATION IN MALAYSIA'S EDUCATION SYSTEM
}

\author{
Noorilham Ismail \\ Universiti Sains Malaysia (USM) \\ Malaysia \\ noorilham_ismail@yahoo.com
}

\author{
Mohd Kasturi Nor Abd Aziz \\ Universiti Malaysia Perlis (UniMAP) \\ Malaysia \\ kasturi@unimap.edu.my
}

\section{Zarifah Arsani}

Universiti Sains Malaysia (USM)

Malaysia

zarf5994@gmail.com

\section{Makmur Haji Harun}

Universiti Pendidikan Sultan Idris (UPSI)

Malaysia

makmur@fbk.upsi.edu.my

\begin{abstract}
Abstrack
The implementation of the National Education Philosophy (NEP) at each stage of learning in the Malaysian education system will be the subject of this study. The primary goal that will be stressed is the implementation of the educational philosophy at the primary, secondary, and higher education levels. The emphasis would be on the areas covered in each level of education, whether academic or co-curricular in nature. This analysis will depend on educational reports from the Malaysian Ministry of Education, as well as memoirs, books, and newspapers. Such information will be analysed, compiled, and detailed in an authoritative and insightful narrative statement. Finally, this study will demonstrate that the use of NEP in Malaysian education has been consistent since its inception and continues to this day.
\end{abstract}

Keywords: National Education Philosophy, Malaysia, education system

\begin{abstract}
Abstrak
Penyelidikan ini akan menumpukan pembahasannya terhadap penerapan Falsafah Pendidikan Nasional (FPN) dalam setiap tingkat pembelajaran melalui sistem pendidikan Negara Malaysia. Objektif utama yang akan diberi penekanan adalah dari segi penerapan falsafah pendidikan tersebut di tingkat sekolah dasar, sekolah menengah dan institut pendidikan tinggi. Penekanan akan dibuat terhadap bidang-bidang yang terkandung dalam setiap tingkat pendidikan baik permalahan tersebut bersifat akademis maupun keaktifan dalam ekstra kurikuler. Penyelidikan ini akan menggunakan sumber-sumber dalam bentuk laporan pendidikan dari Kementerian Pendidikan Malaysia yang turut didukung dengan sumber-sumber lainnya seperti memoir, buku-buku dan tidak terkecuali surat khabar. Informasi dari sumber-sumber tersebut akan dianalisa, disusun, dan diperincikan dalam satu huraian naratif yang autoritatif dan informatif. Pada akhirnya, penyelidikan ini akan membuktikan bahwa penerapan terhadap FPN dalam sistem pendidikan di Malaysia adalah konsisten sejak dari awal pengenalannya sehingga ke hari ini.
\end{abstract}

Kata Kunci: Falsafah Pendidikan Nasional, Malaysia, sistem pendidikan

Program Studi Pendidikan Guru Madrasah Ibtidaiyah

STAI Al-Azhar Menganti Gresik, Indonesia 
ZAHRA: Research And Tought Elmentary School Of Islam Journal Vol. (2 ) (2), (Agustus)(2021), (Halaman)(99-

\section{Pendahuluan}

"Pendidikan di Malaysia adalah suatu upaya berterusan ke arah lebih mengembangkan potensi individu secara menyeluruh dan bersepadu untuk melahirkan insan yang seimbang dan harmonis dari segi intelek, rohani, emosi dan jasmani, berdasarkan kepercayaan dan kepatuhan kepada Tuhan. Usaha ini adalah bertujuan untuk melahirkan rakyat Malaysia yang berilmu pengetahuan, berketerampilan, berakhlak mulia, bertanggungjawab dan berkeupayaan mencapai kesejahteraan diri serta memberikan sumbangan terhadap keharmonian dan kemakmuran keluarga, masyarakat dan negara (Zahid, 2020)." Petikan tersebut merupakan Falsafah Pendidikan Nasional (FPN) yang telah diperkenalkan pada tahun 1987 untuk dunia pendidikan di Malaysia sebagai satu asas kepada pembentukan tujuan bidang pendidikan itu sendiri. Pengenalan kepada falsafah tersebut muncul setelah 30 tahun Malaysia mencapai kemerdekaannya dari 31 Agustus 1957 sehingga tahun-tahun akhir 1980-an. Keberadaan FPN mencerminkan kesungguhan pihak pemerintah negara terutama dalam jajaran Kementerian Pendidikan Malaysia yang dimotori oleh Dato' Sri Anuar Ibrahim pada era Perdana Menteri Malaysia yang keempat, Dr. Mahathir Mohamad. Melalui pembentukan Falsafah Pendidikan Nasional itu, muncul beberapa persoalan, mengapa Malaysia memerlukan waktu 30 tahun setelah merdeka untuk memperkenalkan satu Falsafah Pendidikan Negaranya? Apakah perkara yang telah terjadi sepanjang waktu sebelum Falsafah Pendidikan Nasional itu diperkenalkan? Hal tersebut, hanya dapat dijawab jika ada sedikit sorotan sejarah yang dibuat ke atas perkembangan bidang pendidikan di Malaysia tersebut secara khusus terutama pasca kemerdekaan.

Upaya ke arah menghasilkan satu sistem pendidikan di Malaysia dimulai sejak Tanah Melayu belum mencapai kemerdekaan lagi. Hal berkenaan diperlihatkan melalui penyediaan Laporan Barnes pada tahun 1950 di samping Laporan Fenn Wu pada tahun 1952 (Hussin, 1993). Kedua laporan ini menunjukkan satu kerja baik yang diwariskan oleh pihak pemerintahan British pada masa itu untuk melaksanakan sistem pendidikan bagi penduduk Tanah Melayu yang terdiri dari bangsa Melayu, Cina dan India. Walau bagaimanapun, hal tersebut telah memunculkan pebalahan apabila isu bahasa telah dipermasalahkan oleh golongan imigran yang tidak bersetuju menggunakan bahasa Melayu. Hal ini tidak lain terjadi apabila bibit-bibit adanya pengaruh komunisme yang semakin menyebar khususnya antara penduduk berbangsa Melayu dengan bangsa Cina yang baru saja mendapat kerakyatan sebagai penduduk Malaysia setelah mendapat keputusan dari penanggungjawab yang memegang kuasa antar kaum pada tahun 1950 (Harper, 2001; Ling, 2016). 
ZAHRA: Research And Tought Elmentary School Of Islam Journal Vol. (2 ) (2), (Agustus)(2021), (Halaman)(99111) $\mid 101$

Uji coba penerapan pendidikan yang bersepadu kemudiannya dilanjutkan melalui penyediaan Laporan Razak tahun 1956, setahun sebelum Tanah Melayu mencapai kemerdekaannya. Pengenalan kepada Laporan Razak ini adalah untuk membangun satu sistem Pendidikan secara Nasional berdasarkan Bahasa Melayu sebagai bahasa pengantar di samping kebenaran untuk bahasa-bahasa lainnya yang dituturkan (Kim \& Faizal, 1980). Hasil yang didapatkan dari Laporan Razak ini kemudiannya dimasukkan ke dalam bagian Seksyen 3 dari Ordinan Pelajaran 1957 yang sekali lagi hal ini mendapat penentangan dan reaksi yang kurang menyenangkan dalam kalangan imigran yang telah mendapat kerakyatan pada waktu itu. Keadaan ini akhirnya telah membawa kepada pengekalan sekolah-sekolah vernakular khusus dalam bentuk Sekolah Dasar Jenis Bangsa Cina dan Sekolah Dasar Jenis Bangsa Tamil yang menggunakan bahasa ibundanya masing-masing sebagai bahasa pengantarnya. Hal inilah di antara tantangan perpaduan dalam bidang pendidikan. Sistemnya yang berbagai jenis aliran persekolahan dengan orientasi dan tujuan yang berbeda-beda merupakan tantangan utama dalam konteks persepaduan untuk mengeratkan antar sesama suku bangsa. Sehubungan keberagaman dan perbedaan ini, sekolah secara nasional ditetapkan dengan menggunakan Bahasa Melayu dan menyediakan pendidikan sistem nasional, sedangkan sekolah vernakular menggunakan bahasa ibunda untuk membekalkan pendidikan etnik dan suku bangsa mereka. Dalam hal ini, sekolah secara nasional yang seharusnya menjadi pilihan pertama dan utama untuk orang tua dalam menyekolahkan anak-anak mereka telah didapati tidak lagi disukai oleh kebanyakan orang tua yang bukan berbangsa Melayu (Seong, 2020).

Sejauh dekad pelaksanaannya yang pertama setelah mencapai kemerdekaan, Tanah Melayu (selanjutnya Malaysia) masih tidak dapat menyelesaikan persoalan kesepaduan kaum melalui pendidikan. Permasalahan ini terbukti sebaik saja pemerintah Malaysia memperkenalkan Dasar Kebudayaan Nasional pada tahun 1971 yang akan diterapkan melalui saluran pendidikan. Undang-undang tersebut telah menggariskan tiga perkara penting, seperti:

1. Kebudayaan Nasional hendaklah berdasarkan kebudayaan rakyat asli rantau ini.

2. Unsur-unsur kebudayaan lain yang sesuai dan wajar dapat diterima menjadi unsur Kebudayaan Nasional.

3. Islam menjadi unsur yang penting dalam pembentukan Kebudayaan Nasional (Adam, 2013).

Sekali lagi, usaha ini mendapat penentangan dari mereka yang berbangsa Cina atas kenyataan dasar kebudayaan nasional tersebut yang tidak mengambil kira soal budaya 
berbagai suku kaum bangsa yang terdapat di Persekutuan Kerajaan Malaysia. Permasalahan ini semakin mendapat penentangan pada penghujung tahun 1970-an sebelum memuncak pada tahun 1984 melalui suara-suara surat kabar kebangsaan Cina (Soong, 1985). Lanjutan dari itu, bangsa Cina kemudiannya telah mencetuskan konflik menjelang tahun 1957 melalui isu pelantikan guru dalam kalangan sekolah-sekolah berkebangsaan Cina sehingga membawa kepada agresi Operasi Lalang (Mohamad, 2012). Lebih meruncingnya lagi, apabila partaipartai politik yang dimotori oleh bangsa Cina turut campur tangan dalam isu ini. Maka keadaan tersebut telah dimanipulasi oleh partai-partai politik seperti Malaysia Chinese Association (MCA), Partai Gerakan dan Democratic Asian Party (DAP). Dan situasi tidak menentu tersebut yang bertitik tolak dari soal pendidikan ini diperakui sendiri oleh mantan Perdana Menteri, Tun Dr. Mahathir Mohamad dalam memoir beliau, dengan menyatakan bahwa:

"Dalam suasana ini jugalah pelampau bahasa, budaya dan pendidikan Cina mulai membangkitkan berbagai rasa tidak puas hatinya. Kadang kala ia dibuat secara provokatif. Kumpulan pendidikan Cina mulai membantah pelantikan guru Cina yang tidak berkelulusan sekolah aliran Cina dari memegang jabatan penting di Sekolah Dasar Berkebangsaan Cina (SRJK). Tidak lama kemudian, isu itu dialihkan pula oleh bukan saja DAP, malah MCA dan Gerakan (Mohamad, 2012).“

Inilah seri pertikaian panjang yang telah dinyatakan sebelum ini, jelas telah mewarnai pernak-perniknya perjalanan sistem pendidikan Malaysia sebelum diperkenalkan sistem FPN. Pertikaian-pertikaian tersebut perlu diselesaikan terlebih dahulu untuk memastikan kesepahaman antar sesama suku, kaum agar dapat dipupuk untuk mengelakkan sebarang rasa tidak berpuas hati mereka. Apabila FPN diperkenalkan pada tahun 1887, dasar-dasar penting seperti soal Kepercayaan Kepada Tuhan, pembentukan individu yang seimbang dari segi fisik dan mentalnya telah diberikan penekanan penting. Melalui FPN tersebut, perincian mengenai perbedaan suku kaum tidak dinyatakan untuk memastikan supaya falsafah tersebut dapat terpakai dalam kalangan masyarakat yang berbangsa-bangsa dan bersuku-suku beragam budaya. Soal kepercayaan kepada Tuhan dan pembentukan pribadi yang berketerampilan pula selaras dengan perkara pertama dan kelima dari rukun negara Malaysia yang telah digariskan yaitu kepercayaan kepada Tuhan di samping kesopanan dan kesusilaan.

Selepas FPN diperkenalkan dalam sistem pendidikan di Malaysia, tahap pendidikan dari sekolah hingga ke institut perguruan tinggi telah menunjukkan reaksi tersendiri. FPN telah dijadikan sebagai instrumen penting dalam pembangunan insan mengikut peringkat pendidikan yang telah dilaluinya. Dari peringkat sekolah dasar, sekolah menengah dan 
ZAHRA: Research And Tought Elmentary School Of Islam Journal Vol. (2 ) (2), (Agustus)(2021), (Halaman)(99111) $\mid 103$ institut perguruan tinggi, semuanya telah bergerak selaras dengan FPN yang sememangnya memfokuskan elemen perkembangan jasmani, emosi, rohani dan intelek. Justeru, perkara inilah yang akan diberi penekanan dalam bagian berikutnya menerusi penulisan makalah ini.

\section{Hasil Penelitian dan Diskusi}

\section{A. Sejarah Kemunculan Falsafah Pendidikan Nasional}

\section{Aplikasi Falsafah Pendidikan Nasional di Tingkat Sekolah Dasar}

Sekolah-sekolah di tingkat pendidikan dasar terbagi kepada tiga bagian yaitu Sekolah Kebangsaan (Sekolah Negeri), Sekolah Rendah Kebangsaan (Sekolah Dasar Negeri), dan Sekolah Rendah Jenis Kebangsaan (Sekolah Dasar Negeri Jenis Cina/Tamil/India). Anakanak yang memasuki Kelas 1 di sekolah-sekolah ini telah berumur enam tahun, tetapi belum mencukupi umur tujuh tahun pada tanggal 1 Januari tahun yang berkenaan. Jangka waktu pendidikan di tingkat ini dijalankan hanya selama enam tahun. Pendidikannya pula berbentuk pelajaran umum. Bahasa pengantarnya di Sekolah Kebangsaan (Sekolah Negeri) di seluruh Malaysia adalah Bahasa Malaysia. Walau bagaimanapun sekolah Rendah Jenis Kebangsaan (Sekolah Dasar Negeri Jenis Cina) menggunakan Bahasa Cina sebagai bahasa pengantar sementara Sekolah Rendah Jenis Kebangsaan (Sekolah Dasar Negeri Jenis Tamil/India) pula menggunakan Bahasa Tamil sebagai bahasa pengantar.

Sedangkan di Semenanjung Malaysia dan di Sabah Sekolah Rendah Kebangsaan yang dahulunya Sekolah Rendah Jenis Kebangsaan (Sekolah Dasar Negeri Jenis Inggeris) telah menggunakan Bahasa Malaysia seluruhnya semenjak tahun 1975. Di Sarawak pula perancangan alih bahasa ke Bahasa Malaysia di Sekolah Rendah Jenis Kebangsaan (Sekolah Dasar Negeri Jenis Inggeris) telah dilaksanakan pada tahun 1977 dimulai dengan Kelas 1 (Kementerian Pelajaran Malaysia, 1979). Dan setelah enam tahun di tingkat persekolahan ini, murid-murid sekolah dasar kemudiannya akan mengikuti Ujian Pencapaian Sekolah Rendah (UPSR) atau (EBTANAS) dimulai pada tahun 1988. Ujian evaluasi ini tidak lain adalah untuk mengukur tahap pencapaian seseorang murid tentang apa-apa yang dipelajari oleh mereka di tingkat sekolah dasar. Melalui UPSR ini, FPN telah diterapkan secara tersirat melalui ujian mata pelajaran yang perlu dilalui oleh seorang pelajar tersebut. Mata pelajaran seperti Bahasa Malaysia, Bahasa Inggeris, Sains dan Matematika pada dasarnya menjadi instrumen penting dalam membentuk potensi diri setiap murid. Meskipun UPSR ini telah dihapuskan pada tanggal 28 April 2021 (Berita Harian, 2021), tetapi model ujian penilaian tersebut telah menyumbang tidak sedikit tentang sejarah panjang pendidikan Malaysia khususnya di tingkat sekolah dasar.

Mengambil kira perkembangan teknologi yang begitu pesat berlaku, transformasi kurikulum adalah penting untuk memastikan murid senantiasa dididik dengan pengetahuan, kemahiran dan nilai yang relevan bagi menangani tantangan abad ke-21. Berdasarkan FPN, 
ZAHRA: Research And Tought Elmentary School Of Islam Journal Vol. (2 ) (2), (Agustus)(2021), (Halaman)(99111) 104 proses Pengajaran dan Pembelajaran (PdP) yang perlu dijalankan di bawah Kurikulum Standard Sekolah Rendah (KSSR) adalah berpedoman kepada Dokumen Standard Kurikulum dan Pentaksiran (DSKP). Pernyataan standard terdiri dari standard kandungan pembelajaran yang perlu dicapai oleh murid dalam suatu tempoh waktu dan tahap persekolahan yang memadai. Bentuk dan sistem KSSR adalah perlu berdasarkan enam tunjang utama, yaitu Tunjang Komunikasi, Kerohanian, Sikap dan Nilai, Kemanusiaan, Perkembangan Pisik dan Estetika, Sains dan Teknologi dan Keterampilan Diri. Dalam sistem KSSR, juga telah ditambah dengan Elemen Merentas Kurikulum (EMK) baru, yaitu Kreativiti dan Inovasi (Ismail, 2020).

Untuk kumpulan murid yang berkeperluan khusus, kerajaan Malaysia juga menyediakan tahap persekolahan dimulai dari tingkat sekolah dasar. Hal tersebut menyangkut murid yang istimewa dari segi penglihatan, pendengaran, anggota badan maupun tahap pembelajarannya. Kesediaan kerajaan Malaysia dalam menyediakan ruang dan peluang ini kepada mereka yang istimewa adalah satu kesinambungan dari FPN yang bertujuan untuk menyumbangkan potensi indivindu dan peribadi dari segi jasmani, emosi, rohani dan intelektualnya. Selaras dengan "mewujudkan keterampilan" dalam FPN, murid-murid istimewa ini akan diberikan pendidikan secukupnya sejalan dengan kemampuan dan kecenderungan masing-masing baik dalam bidang akademik maupun ekstra kurikuler. Buktinya, sosok individu seperti Mohamad Ridzuan Mohamad Puzi yang telah dilahirkan melalui sistem pendidikan yang tersedia untuk golongan murid istimewa ini sehingga beliau mendapat medali emas dalam olahraga paralimpik bagi acara 100 meter T36 (Celebral Palsy) di Rio De Janeiro, Brazil pada tahun 2016. Hal tersebut kemudiannya turut disambut baik oleh Kementerian Belia dan Sukan Malaysia (Menteri Pemuda dan Olah Raga Malaysia) pada waktu itu dengan sambutan khusus kepada atlet berkenaan di samping diberikan ganjaran atas prestasi atlet tersebut di tingkat dunia (Mynewshub, 2016).

Melalui kenyataan tersebut, sistem persekolahan Malaysia yang dimulai dari tingkat sekolah dasar memang tidak mengabaikan potensi setiap peribadi. Mereka telah dibentuk sesuai dengan kemampuan dan bidang masing-masing supaya menjadi individu yang dapat menyumbang sesuatu kepada bangsa dan negara. Murid-murid istimewa pula telah sukses memberi sumbangan dalam bentuk prestasi gemilang kepada negara sesuai tujuan dan objektif dalam FPN. Lebih jauh dari itu, individu seperti Profesor Ismail Salleh (lulusan Sekolah Negeri Princess Elizabeth) yang pakar dan ahli dalam bidang ekonomi pernah dijadikan oleh mantan Perdana Menteri Malaysia kelima, Tun Abdullah Ahmad Badawi sebagai Senator di Dewan Negara pada tanggal 18 Disember 2007 (The Star, 2007). Keberadaan Profesor Ismail Salleh di posisi tersebut membuktikan bahwa golongan istimewa yang telah dibentuk dari sekolah dasar lagi hingga ke institut perguruan tinggi adalah berpotensi untuk menyumbang keahlian mereka di tingkat tertinggi negara. Dengan itu, hal ini bukanlah satu usaha sia-sia 
ZAHRA: Research And Tought Elmentary School Of Islam Journal Vol. (2 ) (2), (Agustus)(2021), (Halaman)(99111) $\mid 105$ untuk sebuah bidang pendidikan yang tidak membedakan hak antara mereka baik yang berada di posisi negeri maupun yang memerlukan pendidikan khusus bagi murid istimewa.

Dalam hal ini, ternyata penyediaan tingkat sekolah dasar di Malaysia semestinya tidak keluar dari penyerapan konsep FPN 1987. Upaya ini membuktikan bahwa pihak pemerintah sedikit banyak mempunyai kesadaran untuk menyediakan pendidikan di Malaysia sebagai media untuk membentuk individu dan peribadi yang kemudiannya akan melibatkan diri mereka dengan kehidupan bermasyarakat di masa akan datang. Tanpa mengabaikan perbedaan dari segi hak pendidikan, murid-murid yang istimewa dan murid-murid normal telah diberikan kesempatan yang sama untuk memperoleh ilmu pengetahuan meskipun dari institut atau sekolah yang berbeda. Tidak terhenti hanya di situ, penerapan FPN kemudiannya dilanjutkan ke tingkat sekolah menengah bagi memastikan peruntukan murid yang mencukupi baik dari segi pencapaian akademik maupun pembentukan akhlak atau budi pekerti.

\section{Aplikasi Falsafah Pendidikan Nasional di Tingkat Sekolah Menengah}

Setelah melalui tingkat sekolah dasar, murid-murid dalam sistem pendidikan Malaysia akan melalui tingkat sekolah menengah yang terbagi atas tingkat Menengah Rendah (Sekolah Menengah Pertama) dan tingkat Menengah Atas (Sekolah Menengah Atas). Pendidikan di tingkat menengah rendah menggunakan baik Bahasa Melaysia atau Bahasa Inggeris sebagai bahasa pengantar. Pendidikan di tingkat ini diberikan jangka waktu pembelajaran selama tiga tahun kecuali bagi murid-murid yang berasal dari Sekolah Rendah Jenis Kebangsaan Cina atau Tamil yang perlu mengikuti Kelas Peralihan sebelum memasuki Tingkatan 1 aliran Bahasa Malaysia atau Inggeris (Kementerian Palajaran Malaysia, 1979). Bagi mereka, khusus pembelajaran di tingkat ini adalah selama empat tahun. Sekolah-sekolah di tingkat pendidikan Menengah Atas, seperti juga di tingkat pendidikan Menengah Rendah, menggunakan dua bahasa pengantar, yaitu Bahasa Malaysia dan Inggeris. Berdasarkan kepada rencana peralihan bahasa, pendidikan di tingkat ini akan diberi bekalan bahasa Malaysia sebagai bahasa pengantar sepenuhnya dari Tingkatan 4 sehingga ke Tingkatan 5 pada tahun 1980 (Kementerian Pelajaran Malaysia, 1979).

Saat murid-murid memasuki Tingkatan 4, mereka wajib mengikuti Peperiksaan Sijil Pelajaran Malaysia (SPM) (EBTANAS) berdasarkan mata pelajaran yang telah diambil dari Tingkatan 4 sampai Tingkatan 5. Bagi sistem ujian ini, setiap murid diwajibkan untuk mengikutinya karena ijazah ujian akhir (sijil peperiksaan) tersebut beguna sebagai 'tiket' untuk melanjutkan pelajaran ke tingkat berikutnya di samping kegunaan kepada sektor-sektor pekerjaan tertentu. Dari sudut yang lain, pelaksanaan SPM (EBTANAS) ini juga mendapat persaingan dari organisasi atau lembaga bukan milik pemerintah yang diadakan oleh mereka dari bangsa Cina khususnya persatuan seperti Dongjiauzong (Sua, 2005). Persatuan ini dikendalikan oleh aktivis Cina dan guru-guru berbangsa Cina dengan tuntutan mereka supaya pihak pemerintah Malaysia menyediakan satu ijazah hasil ujian untuk bangsa Cina setingkat 
ZAHRA: Research And Tought Elmentary School Of Islam Journal Vol. (2 ) (2), (Agustus)(2021), (Halaman)(99111) $\mid 106$ dengan SPM yaitu The Unified Examination Certificate (UEC). Walau bagaimanapun, sistem pendidikan Malaysia masih lagi berlandaskan kepada ijazah SPM sebagai standar kelayakan untuk semua murid sekolah selain dari kegunaannya yang lain sebagai media penyatuan dalam sistem pendidikan.

Selain itu, sistem pendidikan Malaysia juga telah menyediakan peringkat Tingkatan 6 yang disebut sebagai peringkat pra-Universitas. Melalui tahapan ini, pelajar perlu mengikuti Tingkatan 6 Dasar dan Tingkatan 6 sebelum mereka menyambung pelajarannya ke tingkat Sarjana di kampus manapun atau institut pendidikan yang lebih tinggi. Pada tahun 2012, sistem ini telah diperkenalkan dalam bentuk sistem persemester sesusai dengan tingkatan Diploma apabila seorang pelajar perlu mencapai nilai tertentu, selain tugasan khusus yang perlu diselesaikan di semester terakhir. Bertitik-tolak dari inilah FPN telah diterapkan di peringkat Sekolah Menengah sebagai intisari penting untuk membentuk seorang individu yang cemerlang dan gemilang dari segi jasmani, emosi, rohani, dan intelektualnya.

Permasalahan ini kemudiannya di dukung dengan berbagai peraturan sistem pendidikan melalui pemerintah baik peraturan yang bersifat jangka pendek ataupun jangka panjang. Sebagai contoh, pengenalan tentang peraturan Satu Murid Satu Sukan (Olahraga) (1M 1S) yang telah diperkenalkan untuk membentuk pelajar yang seimbang dari segi prestasi akademik dan kegiatan ekstra kurikulernya. Justeru, murid-murid dari peringkat Sekolah Menengah Dasar, dan Sekolah Menengah Atas dan Pra-Universitas yang sesuai dengan ketentuan tersebut sebagai satu keserasian dalam sistem pendidikan di Malaysia. Kenyataan dalam buku pedoman 1M 1S yang dikeluarkan oleh Bagian Olahraga Kementerian Pelajaran Malaysia (2011) menyebutkan, bahwa:

"Peraturan 1M 1S adalah program pembangunan olahraga di sekolah yang mewajibkan setiap murid dari kelas 2 di sekolah Dasar sehingga kelas 6 di Sekolah Menengah perlu mengikuti sekurang-kurangnya satu aktivitas olahraga yang dikendalikan secara terencana dan sistematik. Peraturan 1M 1S adalah berasaskan kepada prinsip-prinsip dasar perkembangan fisik murid-murid. Justeru itu, peraturan 1M 1S adalah diadakan untuk merealisasikan Falsafah Pendidikan Nasional (Bagian Olahraga Kementerian Pelajaran Malaysia, 2011).”

Pada tahun 2013, satu pelan rancangan jangka panjang, telah diperkenalkan oleh Kementerian Pendidikan Malaysia dalam bentuk Pelan Pembangunan Pendidikan Malaysia (PPPM) 2013-2025. Upaya ini tidak lain adalah untuk memastikan setiap anak-anak yang menjadi warganegara Malaysia wajib mendapat akses pendidikan yang seharusnya melalui tujuan 100\% enrolmen dalam kalangan anak-anak yang sedia ada. Setiap anak-anak warganegara Malaysia, tanpa membedakan tarap ekonomi, etnik, suku atau latar belakangnya semua berhak mendapat akses yang sama dalam pendidikan yang berkualitas bagi melayakkan mereka mencapai potensinya masing-masing. Komitmen ini termasuklah memastikan semua murid mendapat tempat di sekolah dan anak-anak yang tidak bersekolah 
ZAHRA: Research And Tought Elmentary School Of Islam Journal Vol. (2 ) (2), (Agustus)(2021), (Halaman)(99111) 107

didekati secara proaktif, serta memastikan semua murid memenuhi standard minimum yang diterimanya, yaitu perlu lulus mata pelajaran dasar Bahasa Malaysia, Bahasa Inggeris, Matematika, Sains, Sejarah dan Pendidikan Agama Islam atau Pendidikan Moral pada akhir Kelas 5 (Kementerian Pendidikan Malaysia, 2013).

Pembahasan dalam konteks ini, ide melalui FPN dapat diterapkan supaya setiap pelajar dapat mengenal jati dirinya masing-masing dalam proses mereka menjadi manusia yang berkualitas untuk agama, bangsa dan negara. Hal ini bertitik-tolak dari mata pelajaran yang mereka pelajari seperti sejarah yang berguna sebagai sudut pandang setiap pelajar mengenal latar belakang kebudayaan masyarakatnya yang bersuku-suku bangsa di Malaysia di samping pembangunan negara yang berdaulat dan bermartabat. Mata pelajaran seperti Bahasa Malaysia dan Bahasa Inggeris pula berfungsi untuk meningkatkan daya literasi pelajar untuk menguasai ilmu sains dan matematika yang akan diimbangi melalui pendidikan agama selain pendidikan moral. Hal ini seiring sejalan dengan tujuan pendidikan yang telah digariskan oleh United Nations Educational, Scientific and Cultural Organization (UNESCO) pada tahun 1996 yang menekankan kepada empat objektif yaitu Learning to know, learning to do, learning to be, dan learning to live together" (Razak, 2020).

Keempat tonggak utama tersebut adalah sejalan dengan empat aspek perkembangan utama yang tercatat dalam FPN dengan merangkumi aspek intelektual, jasmani, rohani dan emosi. Kesemua aspek tersebut dapat disejajarkan dengan lengkap sesuai dengan learning to know (belajar untuk mengetahui yang berdasarkan penggunaan ilmu pengetahuan yang luas), learning to do (belajar untuk melakukan dan memupuk kemahiran serta kepandaian dalam menangani berbagai keadaan secara baik), learning to be (belajar untuk mengenal diri yang dapat mengembangkan keyakinan diri, bertindak secara mandiri, berkemampuan membuat penilaian dan bertanggungjawab berdasarkan nilai-nilai murni), serta learning live together (belajar untuk hidup bersama dengan menggembleng kerjasama dan saling bergantungan dan bertindak untuk kebaikan bersama merangkumi ketiga tonggak selainnya) (Razak, 2020).

Rentetan dari itu, proses pembangunan diri dan potensi murid dapat dihasilkan berdasarkan semangat dari FPN yang telah dinyatakan sebelum ini. Lebih signifikan lagi apabila perkara tersebut turut dinikmati oleh murid-murid yang beragam suku bangsa di Malaysia tanpa sebarang prejudis maupun diskriminasi kehidupan sosialnya. Melalui sistem pendidikan yang telah digabungkan tersebut melalui konsep yang telah digariskan oleh FPN, murid-murid tamatan Pendidikan Sekolah Menengah layak untuk melanjutkan pelajarannya ke tingkat lebih tinggi di Institut Pendidikan Tinggi. Pada peringkat seterusnya itu, tantangan dan usaha untuk membentuk keperibadian individu yang selaras dengan FPN dapat dilaksanakan melalui beragam mata kuliah yang ditawarkan di tingkat institut pendidikan tinggi seperti yang akan dijelaskan selepas ini.

\section{Aplikasi Falsafah Pendidikan Nasional di Tingkat Institut Perguruan Tinggi}


ZAHRA: Research And Tought Elmentary School Of Islam Journal Vol. (2 ) (2), (Agustus)(2021), (Halaman)(99111) 108

Bagi institut pendidikan tinggi, penerapan terhadap falsafah pendidikan nasional itu tidak terkecuali sama sekali. Elemen-elemen yang berkaitan dengan pembangunan insan dari segi jasmaniah dan rohaniahnya telah memberi fokus kepada mana-mana institut pendidikan tinggi di Malaysia yang terdiri dari universitas, kolej universitas, kolej swasta, pusat kemahiran dan pelatihan, di samping maktab perguruan. Hal ini penting bagi meneruskan terhadap penerapan falsafah pendidikan berkenaan yang telah diterapkan di tingkat Sekolah Dasar dan Sekolah Menengah sebelum ini. Penekanan di tingkat institut pendidikan tinggi bahkan menjadi lebih penting karena individu lulusan dari peringkat ini akan terlibat langsung dengan masyarakat di samping sektor pekerjaan yang menjadi realitas sebenar pengaplikasian dan pengabdian yang menjadi hasil dari pendidikan sewaktu individu belajar dari perguruan tinggi. Dengan adanya penerapan falsafah pendidikan nasional ini, setidaknya setiap individu yang dilahirkan dari institut pendidikan berkenaan akan menjadi asset penting sebagai sumber daya manusia dalam membawa kesejahteraan bagi masyarakat, agama dan negara.

Sebagai pernyataan yang menjadi dasar kepada Sistem Pendidikan Negara, Kementerian terus menjadikan FPN sebagai asas kepada pendidikan seimbang untuk mengembangkan aspirasi pelajar dan mahasiswa. Berdasarkan kedua Pelan Pembangunan Pendidikan Malaysia (PPPM) 2013-2025 dan Pelan Pembangunan Pendidikan Malaysia (Pendidikan Tinggi) 2015-2025, sistem pendidikan dari peringkat Pra Sekolah sehingga ke tingkat Pendidikan Tinggi sekarang ini mempunyai kesinambungan dengan misi keberhasilan dan kepentingannya kepada setiap mahasiswa di institut pendidikan tinggi (Kementerian Pendidikan Malaysia, 2013; Kementerian Pendidikan Malaysia, 2015). Kementerian menggariskan Enam Aspirasi Murid dalam PPPM 2013-2025, hanya mengubah frasa dan susunan berdasarkan kepentingan dalam pendidikan tinggi. Aspirasi pelajar pendidikan tinggi mempunyai Enam sumbangan, dimulai dengan etika dan kerohanian, kepemimpinan, jati diri nasional, penguasaan bahasa, kemahiran berpikir dan ilmu pengetahuan (Ismail, 2020).

Selaras dengan itu, institut pendidikan tinggi di Malaysia telah dibentuk dalam rangka yang seimbang antara ilmu sains dan ilmu kemanusiaan kepada individu yang layak menyambung pelajarannya ke peringkat tersebut. Untuk bidang sains, berbagai lapangan kerja dan bidang ilmu yang telah ditawarkan baik bidang kedokteran, tehnik, Aero angkasa, pertanian maupun sains makanan dan sebagainya. Dalam konteks ilmu kemanusiaan pula, bidang seperti sejarah, linguistik, geografi, bahasa dan kesusasteraan serta sains kemasyarakatan turut ditawarkan dalam upaya mempelbagaikan bidang pendidikan. Kedua bidang tersebut telah menjadi komponen penting dalam beberapa institut pendidikan tinggi seperti Universiti Sains Malaysia (USM), Universiti Malaya (UM), Universiti Islam Antarabangsa Malaysia (UIAM) dan Universiti Pertahanan Nasional Malaysia (UPNM). Pendekatan ini tidak lain adalah untuk memastikan pembangunan insan yang bergelar mahasiswa dan mahasiswi tersebut lebih fleksibel tanpa penekanan ilmu sains secara mutlak 
ZAHRA: Research And Tought Elmentary School Of Islam Journal Vol. (2 ) (2), (Agustus)(2021), (Halaman)(99111) 109 ataupun bidang ilmu kemanusiaan yang konservatif. Melalui bidang-bidang di universitas ini, FPN dapat diterapkan dari segi perkembangan jasmaniah, pembangunan emosi, pemantapan rohani dan pengukuhan intelektual. Pada akhirnya, individu yang dilahirkan dari institut pedidikan tinggi tersebut diharapkan dapat menyumbang kepada masyarakat ke arah kemajuan agama, bangsa dan negara.

Untuk membuktikan bahwa aplikasi FPN ke dalam institut pendidikan tinggi sebagai sesuatu yang bukan hanya retorika semata, terdapat institut pendidikan tinggi yang telah dianugerahkan dengan satu program khusus. Program tersebut dilahirkan dengan sebutan "APEX" (Accelerated Programme for Excellence). Melalui gelaran ini, Kementerian Pedidikan Tinggi Malaysia telah memberi otoritas kepada universitas tersebut baik dalam bentuk hal kemahasiswaan, penetapan program dan jurusan universitasnya dan pembentukan identitas universitas itu sendiri. Sebagai contoh, Universiti Sains Malaysia, merupakan sebuah universitas yang terletak di Pulau Pinang telah dianugerahkan dengan gelaran kampus APEX pada tahun 2008 sebagai universitas pertama di Malaysia yang menerima gelaran tersebut. Menteri Pendidikan Tinggi Malaysia tahun 2008, Datuk Seri Mohamed Khaled Nordin menyifatkan kelayakan USM sebagai sebuah universitas bertarap APEX bertitik tolak dari tiga kriteria dari segi kesediaan, rancangan transformasi dan kesedian untuk berubah (Berita Harian, 2008).

Dari segi kesinambungan FPN dengan status APEX yang diberikan kepada Universiti Sains Malaysia, hal tersebut telah dinyatakan melalui program dalam lingkungan univerisitas itu sendiri. Buktinya, program dan aktivitasnya yang berorientasikan objektif kelestarian jelas diperlihatkan dalam acara dan aktivitas yang melibatkan mahasiswa dan mahasiswi di univerisitas. Penekanan kepada konsep kelestarian itu, tidak terbatas kepada pembentukan nilai insan semata-mata tetapi juga turut melibatkan tanggungjawab untuk mewujudkan dan memastikan kesinambungan dalam bentuk lingkungan persekitaran universitasnya. Di samping itu, pembangunan insan turut diberi perhatian terhadap golongan mahasiswa yang istimewa yang turut menjadi sebagian dari perancangan pembaruan sebagai kampus Universitas APEX. Dengan itu, pembangunan peribadi dan potensi diri mahasiswanya dapat dibentuk dengan acuan yang telah tersedia dalam FPN yaitu "Melahirkan rakyat Malaysia yang berilmu pengetahuan, berketerampilan, berakhlak mulia, bertanggung jawab dan berupaya mencapai kesejahteraan diri serta memberikan sumbangan terhadap keharmonian dan kemakmuran keluarga, masyarakat dan negara" (Zahid, 2020).

Melalui konteks ini, institut pendidikan tinggi seharusnya menjadi tempat yang tidak terpisahkan dari FPN baik dalam ruang lingkup pendidikan maupun pengaplikasian ilmu pengetahuan. Melalui program dan aktivitas segala bidang di sebuah universitas, setiap individu akan melalui proses yang sama dari segi pengembangan dan pembangunan kualitas 
ZAHRA: Research And Tought Elmentary School Of Islam Journal Vol. (2 ) (2), (Agustus)(2021), (Halaman)(99111) $\mid 110$

diri tanpa mengira tarap setiap individu. Secara tidak langsung, usaha tersebut adalah satu bentuk pendemokrasian pendidikan di peringkat negara bahkan selaras dengan tuntutan di tingkat dunia secara global. Tanpa usaha yang bersepadu dari pihak institut pendidikan tinggi, maka mustahil untuk penerapan FPN dapat dilaksanakan dengan baik yang sejajar dengan perubahan dan keperluan pendidikan mengikut peredaran zaman. Hal ini bertepatan dengan ungkapan ilmuan dunia pendidikan dari Brazil yaitu, Paulo Freire yang mentakan, bahwa "Reading the word and the world". Hal tersebut bermaksud, keupayaan untuk mendalami satu ilmu pengetahuan dari bahan bacaan dan institut pendidikan perlulah mampu membentuk seseorang tersebut supaya memahami dunia di sekelilingnya untuk melakukan perubahan yang bermanpaat kepada masyarakat (Freire \& Donaldo, 1987).

\section{Simpulan}

Kesimpulannya, FPN merupakan inti sari penting yang memperkokoh sistem pendidikan Malaysia khususnya setelah pengenalan kepada falsafah tersebut pada tahun 1987. Kesinambungan penerapan FPN tersebut yang kemudiannya telah diperaktekkan dari semua tingkat dari sekolah dasar, sekolah menengah sehingga ke institut perguruan tinggi. Permasalahan tersebut bukanlah retorika semata-mata karena hal tersebut telah disalurkan melalui dasar-dasar pendidikan di samping programprogram tertentu dalam setiap tingkat pendidikan yang sudah ada. Murid-murid yang menjadi golongan sasaran pada penerapan falsafah ini dibentuk sesuai dengan tujuan pendidikan negara yang bersifat fleksibel sesuai dengan perkembangan pendidikan di tingkat dunia dan global. Latar belakang sejarah juga ikut mempengaruhi pengenalan kepada FPN dalam upaya menyatukan masyarakat yang bersuku-suku dan berbangsa-bangsa yang menjadi dasar pembentukan sebuah negara Malaysia. Penarafan FPN ini bukanlah satu yang bersifat sesuatu yang semu, bahkan sebaliknya individu menyesuaikan dengan keperluan zaman dengan memperhitungkan semua lapisan masyarakat dan golongan murid-murid yang memerlukannya. Pada akhirnya, sistem pendidikan di Malaysia terus berkembang dengan tidak mengabaikan sebuah falsafah pendidikan dalam perjalanan pembangunan sebuah negara dan bangsa yang merdeka dengan masyarakatnya tetap berpendidikan.

\section{Daftar Pustaka}

Adam, A. (2013). Melayu Nasionalisme Radikal dan Pembinaan Bangsa. Kuala Lumpur: Penerbit Universiti Malaya.

Berita Harian. 2008. USM Perlu Bajet RM830 juta: Pelan Transformasi APEX Tumpu Pembangunan Modal Insan, 15 September 2008. http://eprints.usm.my/id/eprint/2832

Berita Harian. 2021. UPSR Mansuh, PT3 Dibatalkan, 28 April 2021. https://www.bharian.com.my/berita/nasional/2021/04/811621

Freire, P. \& Donaldo, M. 1987. Literacy: Reading the Word and the World. New York Routledge.

Harper, T. N. 2001. The End of Empire and the Making of Malaya. United Kingdom: Cambridge University Press. 
ZAHRA: Research And Tought Elmentary School Of Islam Journal Vol. (2 ) (2), (Agustus)(2021), (Halaman)(99111) $\mid 111$

Hussin, S. 1993. Pendidikan Di Malaysia: Sejarah, Sistem dan Falsafah. Kuala Lumpur: Dewan Bahasa dan Pustaka.

Ismail, H. 2020. Pelaksanaan Falsafah Pendidikan Kebangsaan: Pengalaman di Peringkat Sekolah dan Institusi Pengajian Tinggi. Dalam Razak, D. A. \& Hashim, R. (ed.), Pentafsiran Baharu Falsafah Pendidikan Kebangsaan dan Pelaksanaannya Pasca 2020. Gombak: IIUM Press.

Bagian Sukan Kementerian Pelajaran Malaysia. 2011. 1 Murid 1 Sukan: Buku Panduan Pelaksanaan Dasar Satu Murid Satu Sukan (IM 1S). Putrajaya: Bagian Sukan Kementerian Pelajaran Malaysia.

Kementerian Pelajaran Malaysia. 1979. Laporan Jawatankuasa Kabinet Mengkaji Pelaksanaan Dasar Pelajaran, 7hb November 1979. Kuala Lumpur: Kementerian Pelajaran Malaysia.

Kementerian Pendidikan Malaysia. 2013. Pelan Pembangunan Pendidikan Malaysia 2013-2025. Putrajaya: Kementerian Pendidikan Malaysia.

Kementerian Pendidikan Malaysia. 2015. Pelan Pembangunan Pendidikan Malaysia (PPPM) Pendidikan Tinggi 2015-2025. Putrajaya: Kementerian Pendidikan Malaysia.

Kim, K. K. \& M. Faizal. 1980. Pendidikan di Malaysia Dahulu dan Sekarang. Kuala Lumpur: Persatuan Sejarah Malaysia.

Ling, Ho Hui. 2016. Communities Liaison Committee: Ke Arah Menyelesaikan Isu-Isu Perkauman di Tanah Melayu. Dalam A. Arifin \& A. R. Haji Ismail (ed.). 'Di Sebalik Tabir' Sejarah Politik Malaysia 1945-1957. Pulau Pinang: Penerbit USM.

Mohamad, M. 2012. Doktor Umum: Memoir Tun Dr. Mahathir Mohamad. Petaling Jaya: MPH Group Publishing.

Mynewshub. 2016. Tiga Jagoan Buktikan Tiada Yang Mustahil dalam Dunia. 13 September 2016. https://www.mynewshub.tv/utama-sensasi/tiga-jagoan-dunia-buktikan-tiada-yang-mustahildalam-dunia/

Razak, D. A. 2020. Falsafah Pendidikan Kebangsaan Sebagai Wahana Global dan Antarabangsa. Dalam Razak, D. A. \& Hashim, R. (ed.), Pentafsiran Baharu Falsafah Pendidikan Kebangsaan dan Pelaksanaannya Pasca 2020. Gombak: IIUM Press.

Sua, T. Y. 2005. Politik Dongjiauzong: Dalam Pendidikan Vernakular Cina di Semenanjung Malaysia. Pulau Pinang: Penerbit Universiti Sains Malaysia.

Seong, T. K. 2020. Falsafah Pendidikan Kebangsaan sebagai Penyelesaian Pendidikan Pelbagai Aliran di Malaysia. Dalam Razak, D. A. dan Hashim, R. (ed.), Pentafsiran Baharu Falsafah Pendidikan Kebangsaan dan Pelaksanaannya Pasca 2020. Gombak: IIUM Press.

Soong, K. K. 1985. National Culture and Democracy. Petaling Jaya: Penerbit Kersani Sdn. Bhd.

The Star. 2007. First Disabled Senator Takes Oath. 19 December 2007. https://www.thestar.com.my/news/nation/2007/12/19/first-disabled-senator-takes-oath

Zahid, Wan Mohd. 2020. Falsafah Pendidikan Kebangsaan: Sejarah dan Matlamat. Dalam Razak, D. A. \& Hashim, R. (ed.), Pentafsiran Baharu Falsafah Pendidikan Kebangsaan dan Pelaksanaannya Pasca 2020. Gombak: IIUM Press. 